Apoceruloplasmin copper deficiency holoceruloplasmin kinky hair syndrome neonate

umbilical cord

Wilson's disease

\title{
Determination of Apoceruloplasmin by Radioimmunoassay in Nutritional Copper Deficiency, Menkes' Kinky Hair Syndrome, Wilson's Disease, and Umbilical Cord Blood
}

\author{
ICHIRO MATSUDA, THOMAS PEARSON, AND NEIL A. HOLTZMAN ${ }^{(25)}$ \\ Genetics Unit, Department of Pediatrics, School of Medicine, The Johns Hopkins University, \\ Baltimore, Maryland, USA
}

\section{Extract}

Radioimmunoassay can detect as little as $10 \mathrm{ng}$ apoceruloplasmin. Interference by holoceruloplasmin is overcome by using an antiapoceruloplasmin antibody absorbed with holoceruloplasmin and by correcting for the relatively small inhibition of binding of apoceruloplasmin to absorbed antibody caused by holoceruloplasmin. The apoceruloplasmin concentration in infants with nutritional copper deficiency $(2.9 \pm 0.9 \mathrm{mg} / 100 \mathrm{ml})$, Menkes' kinky hair syndrome $(1.4 \pm$ $0.5 \mathrm{mg} / 100 \mathrm{ml})$, and Wilson's disease $(2.7 \pm 2.0 \mathrm{mg} / 100 \mathrm{ml})$ did not differ significantly from normal $(3.3 \pm 3.1 \mathrm{mg} / 100 \mathrm{ml})$ despite significant reductions $(P<\mathbf{0 . 0 1})$ in the concentration of holoceruloplasmin in each of these conditions. In umbilical cord blood from normal neonates, however, the concentration of apoceruloplasmin $(0.7 \pm 0.5 \mathrm{mg} / 100 \mathrm{ml})$ was significantly lower than normal $(P<\mathbf{0 . 0 1})$, as was the concentration of holoceruloplasmin.

\section{Speculation}

In Wilson's disease the incorporation of copper into nascent apoceruloplasmin, which is probably synthesized at a normal rate and is of normal structure, is reduced. There could be a defect in an enzyme required to catalyze the incorporation or a failure of copper to reach the nascent protein.

In normal neonates the rate of apoceruloplasmin synthesis is probably reduced. This reduction may be responsible for the lower concentrations of both holo- and apoceruloplasmin observed in sera of neonates compared with that of older subjects.

In infants with nutritional copper deficiency and with Menkes' kinky hair syndrome, serum ceruloplasmin, measured by its oxidase activity, which depends on the presence of copper, is markedly reduced $(2,9)$. In Menkes' syndrome the concentration of body copper is low because of defective transport across intestinal mucosal cells (5).

Rats raised on copper-deficient diets also lack ceruloplasmin oxidase activity. They synthesize copper-free apoceruloplasmin at the same rate as copper-containing holoceruloplasmin is synthesized in rats on normal diets. However, the serum coricentration of apoceruloplasmin in hypocupremic rats is much lower than that of holoceruloplasmin in normocupremic rats because it decays more rapidly (11).

Apoceruloplasmin can be detected in the sera of copperdeficient rats by immunoelectrophoresis and precipitin methods (10). In human infants with nutritional copper deficiency these methods failed to reveal any apoceruloplasmin (9). This failure may be due to a greater instability of human apoceruloplasmin compared with rat, to a relative insensitivity of the antibody directed against human ceruloplasmin, or to both. It is also possible that man, unlike the rat, requires copper for the synthesis of apoceruloplasmin. To distinguish between these possibilities a highly sensitive radioimmunoassay for human apoceruloplasmin was developed.

In Wilson's disease, despite a high level of body copper, ceruloplasmin oxidase activity is usually reduced. Either copper fails to bind to nascent apoceruloplasmin, or inadequate amounts of the apoprotein are synthesized, or the protein is unstable. The finding that apoceruloplasmin is present in Wilson's disease sera (3) supports the first possibility but the data are inadequate to permit statistical comparison between apoceruloplasmin concentrations in patients and control subjects. Furthermore, the method employed could have yielded falsely high levels of apoceruloplasmin in subjects with high ceruloplasmin oxidase activity. This problem is overcome by the radioimmunoassay reported here.

In normal neonates, ceruloplasmin oxidase activity is also reduced. As the copper content of the neonatal liver is high (17), either copper is not incorporated into nascent apoceruloplasmin or apoceruloplasmin is not synthesized.

In this paper we describe a radioimmunoassay for human apoceruloplasmin and report holo- and apoceruloplasmin concentrations in normal adults and neonates as well as in the pathologic conditions described above.

\section{EXPERIMENTAL METHODS}

Holo- and apoceruloplasmin were prepared as described previously (10). Ceruloplasmin oxidase activity was determined using $p$-phenylenediamine (PPD) (15). Purified holoceruloplasmin had an $A_{280} / A_{610}$ ratio between 22 and 23 . Apoceruloplasmin retained less than $1 \%$ of the oxidase activity of holoceruloplasmin. 
Immunoelectrophoresis was performed in $0.02 \mathrm{M}$ veronal buffer, $\mathrm{pH} 8.6$, by the technique of Scheidigger (16) and immunodiffusion by the technique of Ouchterlony (14). The arcs were stained for oxidase acitivity with benzidine and for protein with amido black (10).

Whole blood was centrifuged promptly and the serum stored at $-20^{\circ}$ until assay. Except when serum specimens had been collected for diagnostic purposes, and stored frozen, informed consent for these studies was obtained. In some of the controls, and all of the maternal and matched umbilical cord bloods, the specimens were obtained for other studies, for which informed consent was obtained, and used anonymously in these experiments.

\section{PREPARATION OF ANTIAPOCERULOPLASMIN ANTIBODY}

Rabbits were immunized with $900 \mu \mathrm{g}$ apoceruloplasmin in $0.8 \mathrm{ml} 0.9 \% \mathrm{NaCl}, 0.01 \mathrm{M}$ potassium phosphate, $\mathrm{pH} 7.2$ (buffer $A$ ) emulsified with an equal volume of complete Freunds adjuvant. The material was injected into each footpad. Four weeks later an additional $0.4 \mathrm{ml}$ emulsion was injected into each leg. Injections were repeated at 4-5-week intervals. Blood was obtained from the central ear artery 1 week after each booster injection.

Since the antiapoceruloplasmin antibody possesses a component which reacts with holoceruloplasmin (4), antibody specific for apoceruloplasmin was prepared by the absorption technique of Carrico et al. (4) except that the incubation with freshly purified holoceruloplasmin was continued at $4^{\circ}$ for 24 or $48 \mathrm{hr}$ before removing the holoceruloplasmin-anticeruloplasmin precipitate. Traces of holoceruloplasmin were removed from the supernatant by DEAE-Sephadex (A-50) chromatography. The absorbed antibody fraction was concentrated by centrifugation in an ultrafiltration cone (19).

\section{IODINATION AND RADIOIMMUNOASSAY}

Freshly prepared apoceruloplasmin was radiolabeled with ${ }^{125} \mathrm{I}$ by the lactoperoxidase method (12) at room temperature. The reaction mixture consisted of $0.4 \mathrm{mCi}$ carrier-free ${ }_{125} \mathrm{I}(1 \mu \mathrm{l}), 25 \mu \mathrm{l}$ apoceruloplasm $(100 \mu \mathrm{g} / \mathrm{ml}$ in buffer $A)$, and $10 \mu 10.1 \mathrm{M}$ sodium phosphate, $\mathrm{pH}$ 7.9. The reaction was initiated by addition of $1 \mu \mathrm{l} 22 \mathrm{mM} \mathrm{H}_{2} \mathrm{O}_{2}$ and the vial was flicked for 1-2 sec before the addition of $500 \mu 10.1 \mathrm{M}$ sodium phosphate, $\mathrm{pH}$ 7.9. Iodinated apoceruloplasmin was chromatographed on Sephadex G-100 equilibrated with $0.3 \mathrm{M}$ sodium acetate, $\mathrm{pH} 5.8$, and subsequently on DEAE-Sephadex (A-50) equilibrated with the same buffer. Apoceruloplasmin was eluted with $0.5 \mathrm{M}$ sodium acetate, $\mathrm{pH} 5.8$. The specific activity of the ${ }^{125} \mathrm{I}$-labeled apoceruloplasmin was between 15 and $20 \mu \mathrm{Ci} / \mu \mathrm{g}$ (1). Over $80 \%$ was precipitated by antiapoceruloplasmin antibody added in excess. ${ }^{125}$ I-labeled apoceruloplasmin and dilutions of specific antiapoceruloplasmin antibody were kept at $4^{\circ}$ in $1 \%$ bovine serum albumin in buffer $A$.

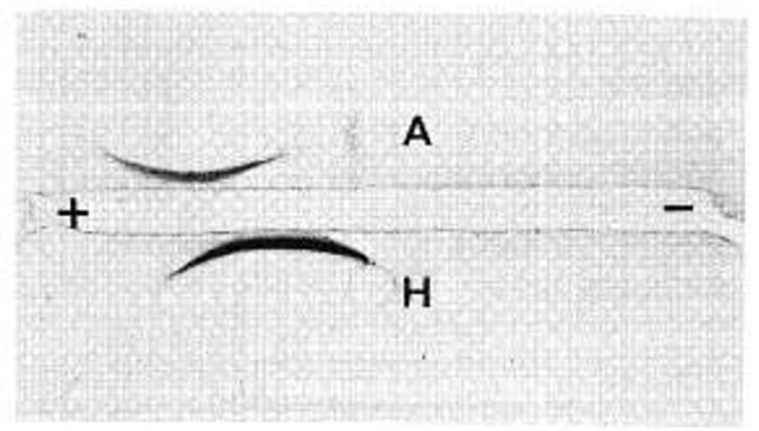

Fig. 1. Immunoelectrophoresis of purified human apo- $(A)$ and holo$(H)$ ceruloplasmin. Trough contained antihuman serum.
The radioimmunoassay was conducted with approximately $6,000 \mathrm{cpm}$ of $\left({ }^{125} \mathrm{I}\right)$ apoceruloplasmin. Ceruloplasmin antigen was present in a volume of $0.1 \mathrm{ml}$. The first stage, in which rabbit antiapoceruloplasmin antibody reacted with ceruloplasmin, was carried out in a total volume of $1.0 \mathrm{ml}$ in $0.01 \mathrm{M}$ EDTA, buffer $A$ at $4^{\circ}$ for $48 \mathrm{hr}$. Then $0.05 \mathrm{ml}$ of a $1 / 20$ dilution of nonimmune rabbit serum and $0.1 \mathrm{ml}$ goat antirabbit $\gamma$-globulin (20) were added and incubated at $4^{\circ}$ for $24 \mathrm{hr}$. The precipitate was washed once with cold buffer $A$. The radioactivity of the precipitate and the combined supernatant and wash was determined in a Picker Nuclear (21) Autowell II $\gamma$-counter. All samples were run in duplicate or triplicate.

\section{RESULTS}

\section{IMMUNOLOGIC STUDIES}

Immunoelectrophoresis of holo- and apoceruloplasmin employing goat antihuman serum (22) revealed only one arc with each antigen (Fig. 1). Apoceruloplasmin did not stain with benzidine and moved further toward the anode than holoceruloplasmin. Immunodiffusion demonstrated the specificity of the absorbed antibody for apoceruloplasmin (Fig. 2).

\section{RADIOIMMUNOASSAY}

A $1 / 10,000$ dilution of the absorbed antiapoceruloplasmin antibody precipitated $40-50 \%$ of added $\left({ }^{125} \mathrm{I}\right)$ apoceruloplasmin and was employed in further experiments.

Unlabeled apoceruloplasmin inhibits binding of ( $\left.{ }^{1} 25 \mathrm{I}\right)$ apoceruloplasmin in amounts greater than $10 \mathrm{ng}$. Figure 3 demonstrates that holoceruloplasmin has an effect on the binding of $\left({ }^{125} \mathrm{I}\right)$ apoceruloplasmin to antibody, although it is much smaller than the effect of apoceruloplasmin; $100 \mathrm{ng}$ holoceruloplasmin is required to cause the same inhibition of $\left({ }^{125} \mathrm{I}\right)$ apoceruloplasmin precipitation as is caused by $10 \mathrm{ng}$ apoceruloplasmin. Prolonged incubation of the antibody with holoceruloplasmin and repeated absorption failed to prevent this inhibition. It thus became necessary to correct for the amount of holoceruloplasmin present. Its concentration was determined by PPD oxidase assay and serum samples were diluted to contain $0.1 \mu \mathrm{g}$ holoceruloplasmin or less per $0.1 \mathrm{ml}$. Standard concentrations of apoceruloplasmin and holoceruloplasmin were assayed with each experiment. The apoceruloplasmin concentration was calculated by subtracting the holoceruloplasmin present from the total amount measured by the radioimmunoassay. Table 1 indicates that holoceruloplasmin in human serum does not interfere with the recovery of apoceruloplasmin.

The measured concentration of apoceruloplasmin did not change when serum was stored frozen. Repeated freezing an thawing of serum did not affect the apoceruloplasmin level. However, when serum was kept at $4^{\circ}$ for 7 days the apoceruloplasmin concentration increased significantly. No effect of serum dilution on measurements of apoceruloplasmin was found.

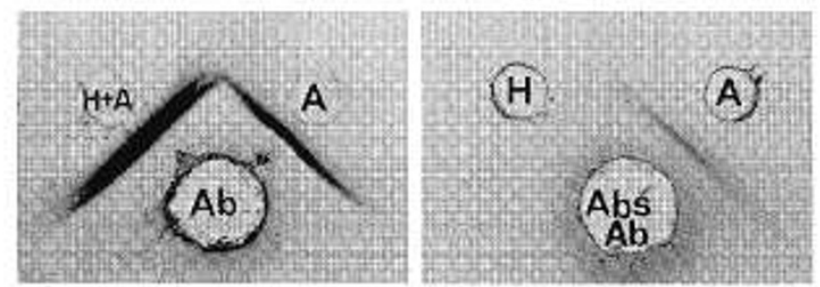

Fig. 2. Immunodiffusion employing antiapoceruloplasmin antibody in the central well. Left: unabsorbed antibody; right: absorbed antibody. $H$ : holoceruloplasmin; $A$ : apoceruloplasmin. 


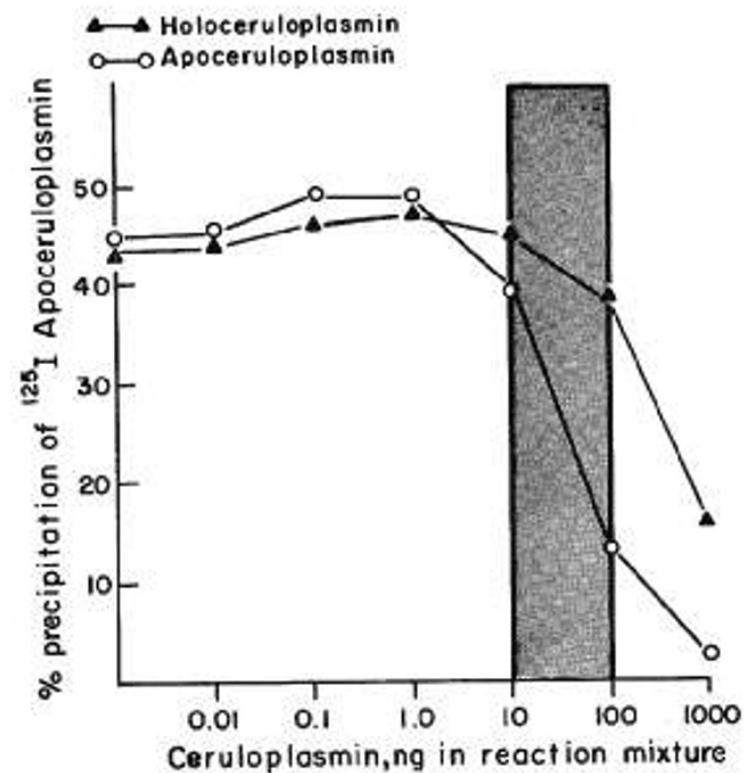

Fig. 3. Radioimmunoassay for apoceruloplasmin. In the first stage either apo- $(\bullet--\bullet)$ or holo- $(\boldsymbol{\wedge}-\mathbf{\Delta})$ ceruloplasmin was incubated with

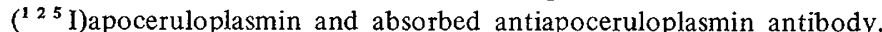
Precipitation of the $\left({ }^{125} \mathrm{I}\right)$ immune complex in the second stage is described under Experimental Methods. The stippled bar indicates the operating range of the assay; with each experiment a standard curve is obtained with amounts of apoceruloplasmin between 10 and $100 \mathrm{ng}$.

Table 1. Recovery of apoceruloplasmin in radioimmunoassay of human serum ${ }^{1}$

\begin{tabular}{cccc}
\hline \multirow{2}{*}{\begin{tabular}{c} 
Apoceruloplasmin $\begin{array}{c}\text { Total ceruloplasmin, ng } \\
\text { added, ng }\end{array}$ \\
\cline { 2 - 3 }
\end{tabular}} & Measured & $\begin{array}{c}\text { Expected } \\
\text { Recovery of } \\
\text { apoceruloplasmin, \% }\end{array}$ \\
\hline 0 & $38^{2}$ & & \\
30 & 68 & 68 & 100 \\
50 & 85 & 88 & 96 \\
\hline
\end{tabular}

${ }^{1}$ Diluted serum in the reaction mixture contained 100 ng holoceruloplasmin (determined by $p$-phenylenediamine assay). This is equivalent to $10 \mathrm{ng}$ apoceruloplasmin in the radioimmunoassay (Fig. 3).

${ }^{2}$ Of the $38 \mathrm{ng}$ determined by radioimmunoassay, $10 \mathrm{ng}$ are due to holoceruloplasmin. Therefore, $28 \mathrm{ng}$ apoceruloplasmin are present. In the next two rows, the total ceruloplasmin expected $=$ apoceruloplasmin added $+28 \mathrm{ng}$ apoceruloplasmin $+10 \mathrm{ng}$ holoceruloplasmin The relatively high concentration of apoceruloplasmin was due to storage of the serum unfrozen.

APOCERULOPLASMIN LEVELS IN CONTROL SUBJECTS, WILSON'S DISEASE, NUTRITIONAL COPPER DEFICIENCY, MENKES' SYNDROME, AND NEONATES

The concentration of apoceruloplasmin in the sera of patients with Wilson's disease, copper deficiency, and Menkes' syndrome was in the same range as it was in control subjects (Table 2). Holoceruloplasmin was, as expected, low in each of these conditions. Apoceruloplasmin concentrations in two Wilson's disease patients not receiving penicillamine were not different from those receiving the drug.

The concentration of apoceruloplasmin was low only in cord blood $(P<0.01)$, although it was high in simultaneously obtained maternal blood. The neonates, from whom the specimens were collected, were full term and apparently normal, as were their mothers. Replicate determinations of either apo- or holoceruloplasmin usually agreed within 5\%. Thus most of the variation shown in Table 2 represent
Table 2. Serum concentration of holo- and apoceruloplasmin in various states

\begin{tabular}{lcc}
\hline & $\begin{array}{c}\text { Holoceruloplasmin, } \\
\mathrm{mg} / 100 \mathrm{ml}^{1}\end{array}$ & $\begin{array}{c}\text { Apoceruloplasmin, } \\
\mathrm{mg} / 100 \mathrm{ml}^{1}\end{array}$ \\
\hline $\begin{array}{c}\text { Control subjects } \\
(\mathrm{n}=21)\end{array}$ & $35.7 \pm 10.0$ & $3.3 \pm 3.1$ \\
$\begin{array}{c}\text { Wilson's disease } \\
(\mathrm{n}=10)\end{array}$ \\
$\begin{array}{c}\text { Copper deficiency } \\
(\mathrm{n}=7)\end{array}$ \\
$\begin{array}{c}\text { Menkes' syndrome } \\
(\mathrm{n}=1)\end{array}$ \\
$\begin{array}{c}\text { Maternal blood at term } \\
(\mathrm{n}=11)\end{array}$ & $4.8^{2} \pm 4.0$ & $2.7 \pm 2.0$ \\
$\begin{array}{c}\text { Cord blood (Infants of } \\
\text { mothers shown above) }\end{array}$ & $1.4^{2} \pm 0.7$ & $2.9 \pm 0.9$ \\
$(\mathrm{n}=11)$ & $09.0^{2} \pm 19.5$ & $1.4 \pm 0.5$ \\
\hline
\end{tabular}

${ }^{1}$ Mean \pm SD.

${ }^{2}$ Differs significantly from control, $t$-test, $P<0.01$.

${ }^{3}$ Five specimens examined.

differences between individuals. When the neonates are excluded the concentrations do not correlate with the ages of the subjects.

Within 2 weeks after the oral administration of copper in an infant with nutritional copper deficiency, holoceruloplasmin concentration increased to $30 \mathrm{mg} / 100 \mathrm{ml}$ but apoceruloplasmin was $2.2 \mathrm{mg} / 100 \mathrm{ml}$, virtually unchanged. In the infant with Menkes' syndrome, intravenous copper resulted in an elevation of serum holoceruloplasmin concentration but apoceruloplasmin concentration remained unchanged. Oral copper had no effect on the serum ceruloplasmin levels in this infant (2).

\section{DISCUSSION}

The presence of normal apoceruloplasmin concentrations in the sera of infants with nutritional copper deficiency and Menkes' syndrome, together with the virtual absence of holoceruloplasmin, resembles the findings in copper-deficient rats $(10)$ in whom apoceruloplasmin synthesis continues at a normal rate despite the reduced availability of copper. Previous failure to detect human apoceruloplasmin in copper deficiency was, we believe, because of insensitivity of the methods.

Our findings confirm those of Carrico and Deutsch (3) that apoceruloplasmin is detectable in "near normal" concentrations in Wilson's disease. Their estimates of apoceruloplasmin in normal individuals could, however, have been falsely high because holoceruloplasmin cross-reacts with absorbed antiapoceruloplasmin antibody. Our method corrects for this occurrence.

The apoceruloplasmin in Wilson's disease sera could be derived from either circulating or hepatic holoceruloplasmin because of lability of the copper ligands. This is unlikely as the copper content of pure ceruloplasmin isolated from patients with Wilson's disease is normal $(8,13)$. Alternatively, the presence of apoceruloplasmin in Wilson's disease could result from failure to incorporate copper into newly synthesized apoceruloplasmin. As a consequence, apoceruloplasmin is released into the circulation where, because of its marked instability, it decays rapidly, resulting in a much lower concentration than if it had copper attached. A defect in an enzyme which catalyzes the incorporation of copper into ceruloplasmin, and into other proteins which normally contain copper $(7,18)$, could explain the findings.

A recent report that there is a low molecular weight protein 
with increased avidity for copper in Wilson's disease liver (6) also is consistent with this finding; copper would never reach the ceruloplasmin-forming sites.

Only in umbilical cord blood was a reduced concentration of apoceruloplasmin observed. This reduction occurred despite very high levels of apoceruloplasmin and holoceruloplasmin in the matched maternal serum obtained at delivery (Table 2). Thus it is unlikely that significant amounts of ceruloplasmin cross the placenta. It appears likely that synthesis of apoceruloplasmin is reduced in neonatal liver despite the presence of adequate copper.

\section{SUMMARY}

A radioimmunoassay capable of detecting very small quantities of apoceruloplasmin in the presence of large amounts of holoceruloplasmin is reported. In nutritional copper deficiency, Menkes' kinky hair syndrome, and Wilson's disease, normal concentrations of serum apoceruloplasmin are present despite marked reductions $(P<0.01)$ in the concentration of holoceruloplasmin. In umbilical cord blood, however, the concentrations of both apo- and holoceruloplasmin are significantly reduced $(P<0.01)$

\section{REFERENCES AND NOTES}

1. Berson, S. A., Yalow, R. S., Glick, S. M., and Roth, J.: Immunoassay of protein and peptide hormones. Metabolism, 13 1135 (1964)

2. Bucknall, W. E., Haslam, R. H. A., and Holtzman, N. A.: Kinky hair syndrome: response to copper therapy. Pediatrics, 52: 653 (1973)

3. Carrico, R. J., and Deutsch, H. F.: Some properties of ceruloplasmin from patients with Wilson's disease. Biochem. Med., 3: 117 (1969).

4. Carrico, R. J., Deutsch, H. F., Beinert, H., and Orme-Johnson, W. $\mathrm{H}$ : Some properties of an apoceruloplasmin-like protein in human serum. J. Biol. Chem., 244: 4141 (1969).

5. Danks, D. M., Stevens, B. J., and Townley, R. R. W.: Menkes' kinky hair disease: Further definition of the defect in copper transport. Science, 179: 1140 (1973).

6. Evans, G. W., Dubois, R. S., and Hambridge, K. M.: Wilson's disease: Identification of an abnormal copper-binding protein. Science, 181: 1175 (1973).

7. Frommer, D.: Abnormality of biliary cōpper excretion in Wilson's disease. Third Symposium on Wilson's Disease, Paris, 1973.

8. Holtzman, N. A., Naughton, M. A., Iber, F. L., and Gaumnitz, B. M.: Ceruloplasmin in Wilson's Disease. J. Clin. Invest., 46: 993 (1967).

9. Holtzman, N. A, Charache, P., Cordano, A., and Graham, G. G. Distribution of serum copper in copper deficiency. Johns Hopkins Med. J., 126: 34 (1970).

10. Holtzman, N. A., and Gaumnitz, B. M.: Identification of an apoceruloplasmin-like substance in the plasma of copper-deficient rats. J. Biol. Chem., 245: 2350 (1970).

11. Holtzman, N. A., and Gaumnitz, B. M.: Studies on the rate of release and turnover of ceruloplasmin and apoceruloplasmin in rat plasma. J. Biol. Chem., 245: 2354 (1970).

12. Marchalonis, J. J.: An enzymic method for the trace iodination of immunoglobulins and other proteins. Biochem. J., 113: 299 (1969).

13. Neifakh, S. A., Vasiletz, I. M., and Shavlovsky, M. M.: Molecular pathology of ceruloplasmin. Biochem. Gen., 6: 231 (1972).

14. Ouchterlony, O.: Antigen-antibody reactions in gels. II. Factors determining the site of the precipitate. Arkiv. Kemi., 1: 43 (1949).

15. Ravin, H. A.: An improved colorimetric enzymatic assay of ceruloplasmin. J. Lab. Clin. Med., 58: 161 (1961).

16. Scheidigger, J. J.: Une micro-methode de l'immu no-electrophorese. Int. Arch. Allerg., 7: 103 (1955).

17. Schroder, H. A., Nason, A. P., Tipton, I. H., and Balassa, J. J. Essential trace metals in man: Copper. J. Chron. Dis., 19: 1007 (1966).

18. Shokeir, M. H. K., and Shreffler, D. C.: Cytochrome oxidase deficiency in Wilson's disease: A suggested ceruloplasmin function. Proc. Natl. Acad. Sci. U.S.A., 62: 867 (1969).

19. Model CF50A, Amicon Corporation, Lexington, Mass.

20. Cappell Laboratories,

21. White Plains, N.Y.

22. Hyland Division, Travanol Labs, Inc., Costa Mesa, Calif.

23. Dr. N. A. Holtzman was a recipient of Public Health Service Research Career Development Award AM 42353 from the National Institute of Arthritis, Metabolism and Digestive Diseases.

24. This research was supported by Research Grant AM 12237 from the National Institute of of Arthritis, Metabolism and Digestive Diseases.

25. Requests for reprints should be addressed to: N. A. Holtzman, M.D., Genetics Unit, Department of Pediatrics, School of Medicine, The Johns Hopkins University, Baltimore, Md. 21205 (USA).

26. Accepted for publication May 21, 1974. 